\title{
LXVIII. Sketch of a classification of the European rocks
}

\section{Henry T. De la Beche Esq. F.R.S}

To cite this article: Henry T. De la Beche Esq. F.R.S (1829) LXVIII. Sketch of a classification of the European rocks, Philosophical Magazine Series 2, 6:36, 440-450, DOI:

10.1080/14786442908675191

To link to this article: http://dx.doi.org/10.1080/14786442908675191

册 Published online: 14 Jul 2009.

Submit your article to this journal $[\pi$

Џ Article views: 2

Q View related articles $\asymp$ 
be expected from the energy and zeal of the indefatigable Bertero.

I can also give you a piece of botanical intelligence from Paris. The celebrated Baron Bory de St. Vincent will in the course of this year proceed to the Antilles; there to examine that favourite tribe, the Ferns, of which he already possesses a very complete collection. He expects to be able to elucidate all the points which Plumier left doubtful. From the wellknown liberality of mind which this enlightened naturalist possesses, I should hope that it would be as agreeable to him as to our Germans who are partial to the Ferns, to have this information communicated in these pages; and, whether before or after his voyage has taken place, to see them thus placed in connection will confer much pleasure on

J. A. Schultes.

LXVIII. Sketch of a Classification of the European Rocks. By Henry T. De la Beche, Esq. F.R.S, \&c.*

$7 \mathrm{O}$ propose in the present state of geological science any 1 classification of rocks which should pretend to more than temporary utility, would be to assume a more intimate acquaintance with the earth's crust than we possess. Our knowledge of this structure is in reality but small, and principally confined to certain portions of Europe; and even in many of these portions we are continually presented with new views and a detail of newly-discovered phænomena by able observers, which so modify our previously received opinions as in many instances almost to amount to a change of them. Still, however, a large mass of information has been gradually collected, particularly as respects this quarter of the world, tending to certain general and important conclusions; among which the principal are, - that rocks may be divided into two great classes, the stratified and the unstratified; - that of the former some contain organic remains, and others do not; - and that the nonfossiliferous stratified rocks, as a mass, occupy an inferior place to the fossiliferous $\uparrow$ strata, also taken as a mass. The next important conclusion is, that among the stratified fossiliferous rocks there is a certain order of superposition, marked by peculiar general accumulations of organic remains, though the mineralogical character varies materially. It has even been supposed that in the divisions termed formations, there are found certain species of shells, \&c. characteristic of each. Of

- Communicated by the Author.

t The tern fossiliferous is here confined to organic remains. 
this supposition, extended observation can alone prove the truth; and in order properly to investigate the subject, geologists must agree to what mass of rocks they should limit the term Formation: if, as some now do, they apply it to every accumulation of ten or twenty beds, which may happen, in the district they have examined, to contain a few shells not found in the strata above and beneath, the investigation is not likely to lead to any extended conclusions.

To suppose that all the formations into which it has been thought advisable to divide European rocks can be detected by the same organic remains in various distant points of the globe, is to assume that the vegetables and animals distributed over the surface of the world were always the same at the same time, and that they were all destroyed at the same moment to be replaced by a new creation, differing specifically if not generically from that which immediately preceded. This theory would also infer that the whole surface of the world possessed an uniform temperature at the same given epoch.

It has been considered, but yet remains to be proved, that the lowest fossiliferous rocks correspond generally in their fossil contents, in places far distant from each other. Let us for the moment suppose this assertion to be correct. To obtain this uniform distribution of animal and vegetable life, it seems necessary, judging from the phænomena we now witness, that there should also have been an uniform temperature over the surface of our planet. To obtain this, solar influence, as it now exists, would be inadequate; we must therefore have recourse to internal heat to produce the effect required. In the present varied temperature of the earth's surface, if we imagine a rock to be formed which should envelop every animal and plant now existing, the fossil contents of one district would differ from the fossil contents of another; if we except man, whose bones would more or less become the characteristic fossils of those portions of the rock which might overlie the present dry land. 'The rock supposed to be now formed would present a striking contrast with the old fossiliferous, and we should have two very distinct accumulations of organic remains. The question arising on such phænomena would be, Has so great a change of organic character been effected gradually or suddenly? To suppose it sudden will not agree with the phænomena presented to us, even by the now known Europeanirocks; and if it be considered gradual, we cannot expect rocks should every where contain the same-organic remain, even in those that have been commonly called secondary? ronsequently the organic remains considered characteristic of any
N.S. Vol. 6. No. 36. Dec. 1829.
$3 \mathrm{~L}$
particular 
particular formation in one part of the world, may not.be found at all in an equivalent formation in another.

Upon the theory that the world cooled in such a manner that solar heat, as now existing, gradually acquired its influence, the warm climate vegetation would gradually be restrained within narrower limits, until it became circumscribed as it now is; consequently all rocks formed within the tropics would probably contain warm climate plants, while these would gradually cease on the $\mathbf{N}$. and $\mathrm{S}$.; so that it would be by no means safe to deduce the kind of Flora that should be found in any given rock in the tropics from the fossil plants discovered in an equivalent rock in Europe. If vegetable life might under such circumstances so vary, there seems no good reason why animal life might not equally differ. To what extent the mass of organic fossils found in any particular European formation or group of formations may exist in equivalent rocks (of Africa or America for instance), remains to be seen. In the present state of our knowledge, it is only safe to state that certain remains have been discovered in a given rock, not that they are absent from it.

The old divisions into primitive, transition, secondary, and tertiary, are now admitted by many persons to be founded on an erroneous view of nature; yet such is the force of habit, that many geologists, aware of the fallacy of these divisions, still continue to use the terms, and we hear nearly as much as ever of transition rocks. Would it not be imagined by a person first directing his attention to the study of geology, that there were three great marked periods, during each of which rocks of a peculiar character, distinct from each other, were formed, and that there was a transition or passage only between the first and second of these. I appeal to those who have examined rocks in the field, and not merely in cabinets and museums, whether or not the student would entertain correct opinions. These divisions may be said to have been made in the infancy of the science, and doubtless contributed much to its present comparatively advanced state; but it should always be recollected that they were formed from limited observations, and were connected with particular theories, which recent and more accurate observations have shown to be any thing but correct. If it shall be proved that there is an occasional passage between the old tertiary and secondary classes, there would appear to be more or less transition throughout the whole series of the stratified rocks, showing that the term transition, at least, is incorrect. A great mass of evidence is, indeed, in favour of a break at 
the epoch of the Exeter Red Conglomerate (Rothe Todte Liegende), resulting from a great derangement in the previously existing rocks, and the grinding and rounding of detached portions of them into gravels, which when comparative tranquillity was restored, were deposited in horizontal beds on the disturbed strata. Yet able observers assert, that there is an occasional passage of these rocks into the coal-measures, upon which they so commonly rest in an unconformable manner. We have now so many instances of great differences in the mineralogical structure of the same formations, either original or consequent on disturbance, that such structure is no longer a character of importance; and it yet remains to be seen how many of the strata supposed to belong to the primitive class are altered rocks.

M. Brongniart's division into "Sediment Rocks" would be both natural and useful were it certain where such rocks commenced, and that all those necessarily included in the class were so formed. This division has been much used in France of late, and would appear infinitely superior to the terms secondary and tertiary.

In offering the annexed sketch of a classification of European rocks to the attention of the reader, it is merely my intention to show that divisions can be made for practical purposes, independent of the theoretical terms primitive, transition, secondary and tertiary; terms which not being founded on an enlarged view of nature, but grounded on peculiar views, now doubted, there would appear no good reason for preserving. It is not presumed that this classification will be adopted, and I am well aware that many just objections can be made to it; but it pretends to nothing beyond convenience : and if geologists could be induced to use something of this kind, or any other that would better answer the purpose of relieving us from the old theoretical terms, I cannot but imagine that the science would derive benefit from the change.

In the accompanying Table, rocks are first divided into stratified and unstratified, a natural division, or at all events one convenient for practical purposes, independent of the theoretical opinions that may be connected with each of these two great classes of rocks. 'The same may perhaps also be said of the next great division; viz. that of the stratified rocks into superior or fossiliferous, and inferior or non-fossiliferous. The superior stratified or fossiliferous rocks are divided into groups, nearly the same as those which I published in the Annales des Sciences Naturelles for August last. I have myself found them useful in practice, more particularly in the examination of districts distant from each other. 
Stratified Rocks. - Group 1. (Alluvial) seems at first sight natural and easily determined; but in practice it is often very difficult to say where it commences. When we take into consideration the great depth of many ravines and gorges which appear to originate in the cutting power of existing rivers, the cliffs even of the hardest rocks which more or less bound any extent of coast, and the immense accumulations of comparatively modern land, as for instance, those great flats on the western side of South America, there is a difficulty in referring these phænomena to the duration of a comparatively short period of time. Geologically speaking, the epoch is recent; but, according to our general ideas of time, it appears to be one that reaches back far beyond the dates usually assigned to the present order of things. Man and the monkey tribe seem to be the most marked new creation of this epoch. I would by no means be supposed to deny that they may not have previously existed, but at present the mass of evidence is against their prior appearance. There seems, indeed, no good reason why man and the monkeys should not have lived as well as the bears and hyænas at periods antecedent to this epoch; but until the remains of the two former be found in rocks proved to be formed previous to this period, it cannot be affirmed that they did*. The animals now existing, considered as a mass, appear to differ specifically from those whose remains are found entombed in the various rocks, gravels, clays, \&c. formed previously to the existing order of things. There are indeed a few exceptions to this observation, but the body of evidence seems to render a new creation presumable.

Group 2. (Diluvial) comprises those gravels so commonly occurring in situations where actual causes could not have placed them, but where, on the contrary, such causes tend to destroy them. The most extraordinary feature of this group is the distribution of those enormous blocks or boulders found so singularly perched on mountains, or scattered over plains far distant from the rocks from whence they appear to have been broken. Many valleys appear to have been scooped out of horizontal or nearly horizontal strata at this epoch; the force which excavated them having acted often upon strata shat-

* Should such observations as those lately made on the caverns of the department of the Gard by M. de Christol (Annales des Mines 1829) be multiplied, and should it be always shown that human bones and pottery are, as is stated to be the case, in these caverns, really of the same date as the hyæna's bones, dung, \&c. with which they are mixed,-we can scarcely refuse to admit that man existed previous to the alluvial epoch; supposing it in all cases proved that these cavern remains are of the same date as those considered of the diluvial period. 
tered and broken into faults. Of course a general modification of the previously existing forms of mountain and valley must have taken place, if we are to consider the catastrophe general. Much information is yet wanting respecting this group, which it is hoped those observers who have been more especially occupied with it, will soon afford us.

Group 3. (Lowest Great Mammiferous) comprises the rocks commonly known as tertiary: they are exceedingly various, and contain an immense accumulation of organic remains, terrestrial, fresh-water, and marine. The recent observations of some able geologists have shown that the upper members of this group approach more closely than was formerly supposed to the existing order of things. We yet require much information respecting even the European rocks composing this class, notwithstanding the labours of those who may almost be said to have devoted their exclusive attention to them. The group is characterized by the first appearance, in the ascending series, of any abundance of the mammiferous animals, many genera of which are now extinct.

Group 4. (Cretaceous) contains the rocks which in England and the North of France are characterized by chalk in the upper part, and sands and sandstones in the lower. The term "cretaceous" is perhaps an indifferent one; for, possibly, the mineralogical character of the upper portion whence the name is derived is local, that is, confined to a particular portion of Europe, and may be represented elsewhere by dark compact limestones or even sandstones. As however the geologists of the present day are perfectly agreed as to what rock is meant when we speak of "the chalk," there seems no objection to retain it for the present. The French geologists have long considered the sands beneath the chalk, known as green-sands, as belonging to the same formation with the chalk. That the fresh-water character of the shells contained in the Wealden rocks is more or less local it seems but rational to infer; for it cannot be imagined that all the waters of the globe became suddenly fresh in order that these rocks might be formed, and as suddenly salt again for the deposition of the green-sands and chalk. Some French geologists moreover consider that in France there is a marine equivalent of the Wealden rocks.

As far as our observations of fossil organic remains have yet extended, it would seem probable that the ammonites and belemnites ceased to exist after the formation of this group; for, as yet, their remains have not been detected in Group 3. Should this, after a greater extent of the world has been examined, be found generally true, it will be a most valuable guide 
in determining the relative ages of this and the previously noticed group in cases where the mineralogical structure is of no avail.

Group 5. (Oolitic) comprises the various members of the oolite or Jura limestone formation, including lias. The term oolitic has been retained upon the same principle as that of cretaceous : in point of fact even in England and the North of France the oolites, properly so called, form but an insignificant part of the mass of rocks known by the name of the oolite formation; this character is also not confined to the rocks in question, but is common to many others. In the Alps and Italy the oolite formation is replaced by dark and compact marble limestones, so that its mineralogical structure is of no value. Saurians would appear to have been abundant in some places. The prevailing fossil characteristic seems the extraordinary quantity of ammonites and belemnites, the remains of which are so numerous in this group. It is remarkable that the nautilus should have been continued down to the present time, and that the other camerated shells which swarmed at this epoch should not now be found. The belemnites do not appear to occur beneath the lias, at least as yet we have no well authenticated instance of such occurrence.

Group 6. (Red Sandstone) contains the variegated marls (Marnes irisées, Keuper) the Muschelkalk, the New Red Sandstone (Grès Bigarré, Bunter Sandstein), the Zechstein, and the Exeter Red Conglomerate (Rothe Todte Liegende). The whole is considered as a mass of conglomerates, sandstones, and marls, generally of a red colour, but most frequently variegated in the upper parts. The limestones may be considered subordinate. Sometimes only one occurs, sometimes the other, and sometimes both, are wanting. There seems no good reason for supposing that other limestones may not be developed in this group in other parts of the world. When the muschelkalk is very compact with broken stems of the lily encrinite ${ }^{*}$, one of its characteristic fossils, it might easily be mistaken for some of the varieties of the carboniferous limestone. In some places the new red sandstone contains an abundance of vegetable remains, at others none can be detected in it. The saurians first appear in the ascending series, at least in any abundance, in this group. As I have before observed, the lower part of this group generally rests unconformably on the inferior rocks, and seems to have resulted from a very general upheaving and fracture of the preexisting strata, accompanied by the intrusion of trap rocks.

* Encrinites moniliformis. Miller. 
Group 7. (Carboniferous) Coal-measures and carboniferous limestone. The former would appear in the greater number of instances to be naturally divided from the group above it, but the latter would seem more allied to that beneath: there is however so much connection in this country between the coal-measures and the carboniferous limestone, that it would appear convenient for the present to keep them together. Judging from Europe, the coal-measures present us with the largest mass of fossil vegetables.

Corals were common, but they occur in as great abundance, if not more plentifully, now ; though the recent species, generally speaking, differ from the fossils. But Productæ, the abundance of which characterizes this group, are now unknown; and the Crinoidea which occur in these rocks in multitudes are very rarely found in a living state.

Group 8. (Graureacke) This may be considered as a mass of sandstones, slates and limestones, in which sometimes one predominates, sometimes the other; the old red sandstones of the English geologists being the upper of its sandstones. Trilobites are the most remarkable and abundant fossils of this epoch, and corals and orthoceratites occur in great numbers. It is difficult to fix the inferior limits of this group.

Group 9. (Lowest Fossiliferous) It is very difficult in the present state of our knowledge to say whether or not this constitutes a separate group from No. 8; and I have here introduced it more in accordance with the views of other geologists than with my own. A difference in mineralogical structure proves nothing; the changes in this respect are so various, that the different appearance of one slate from another, if not shown to occupy a different geological position, is of no value. It has indeed been supposed that the Snowdonian slates are older than the grauwacke series, but we yet require the proof of this.

Inferior or Non-fossiliferous Stratified Rocks. - It would be useless in a sketch of this nature to enumerate the varieties of slates and other rocks that enter into this division, they will readily present themselves to the mind of the geologist; recent observations show that many rocks to all appearance of this division may belong to the preceding. M. Elie de Beaumont, in one of his late letters to me, states, that mounting the Val Bedretto from Airolo to the foot of the Col, which leads into the Haut Vallais, he found "an alternation many times repeated of small beds of a compact and grey-black limestone, and a nearly black limestone mixed with clay slate thickly studded with crystals of garnets and staurotides. Both the 
one and the other of these rocks contain a considerable number of belemnites transformed into white calcareous spar, but of which the general forms and alveoli are nevertheless very visible, and can leave no doubt as to the nature of the fossils. As these limestone beds are the prolongation of those in which the gypsum of the Val Canaria is found, and as these are the same with those in which the dolomite of Campo Longo occurs, we can assure ourselves that all the curious mineralogical phænomena of the St. Gothard have been introduced into beds contemporaneous either with the oolite series or the greensand." Now when such important changes as those noticed by my friend $M$. Elie de Beaumont can be fairly traced, what may we not expect to find in the sequel, when geologists shall cease to be contented with referring a particular mineralogical structure to the old divisions transition and primitive, of which the former seems only to have been created as a geological trap.

Unstratified Rocks.-This great natural division is one of considerable importance in the history of our globe. 'To the rocks composing it, and the forces which threw them up, may be attributed the dislocations and fractures in the stratified rocks every where so common, and in many instances their elevations into lofty mountain ranges. In many of the great chains the trap rocks are visible along their line of elevation, as was first observed by M. Von Buch in the Alps,-on the southern side of which they are exposed at intervals; and it is on this side that there is so much dolomite in the limestones. To assert that igneous rocks cannot be present along the whole of this line because not every where visible on the surface, is like affirming that there is no table beneath a cloth spread on it except in the cases where there may be a few holes. We are too apt in judging of the mass and thickness of rocks to compare them with our own size, and imagine them enormous, expressing surprise at the immense forces which it must have required to raise such masses into mountains; when if they were compared, as they ought to be, with the mass of the world, the thickness becomes trifling, the highest mountains insignificant, and the forces required to raise them comparatively small.

That granitic, trappean, and serpentinous rocks have exercised a great influence on the present position of the stratified rocks, few geologists will doubt. The igneous origin of the two former is also very generally admitted; but though the third is not so generally referred to that origin, I know not how we can deny that it was produced by a cause somewhat similar 
similar to that which produced the others, when we consider its mode of occurrence, more particularly in the Alps and in Italy.

The geological dates of the elevations of mountains is a most important subject, and one on which $M$. Elie de Beaumont read a very interesting paper, in June last, before the Institute of France*. His recent observations have tended to confirm his previous remarks on four of these epochs. 1st. That the Ezgeberge, the Cote d'Or, \&c. have been elevated between the epoch of the Jura limestone and the green-sand and chalk. (Groups 5 and 4 of the annexed Table.) 2nd. That the Pyrenees and Apennines were thrown up between the epoch of the chalk and tertiary rocks (Groups 4 and 3). 3rd. That the Western Alps were raised between the tertiary epoch and the first "terrains de transport" (Groups 3 and 2). 4th. That still later, there was an elevation of mountains, in which were comprised some in Provençe, the Central Alps, \&c.

How far the igneous rocks have been connected with these phænomena remains to be seen; but, as before stated, it is by no means fair to infer that because not seen on the surface they do not exist beneath. Volcanoes, properly so called, both existing and extinct, seem to have exerted a minor influence in the elevation of strata compared with that exerted by the igneous rocks which were shot up previous to the action of these volcanoes. Elevations of land do however take place apparently from the causes that produce volcanoes; and of these the rise of land noticed in Chili by Mrs. Maria Graham, in consequence of the earthquake of 1824, is a striking example.

Should the annexed Table succeed in calling the attention of geologists to other divisions than those made in the infancy of the science, and grounded on particular theories, one supposing three great epochs and a transition between the first and second of these, another considering rocks divisible into two great classes, a primary and secondary, the primary containing organic remains in its upper part,-my object will, as I before stated, be fully answered. We are yet acquainted with so small a portion of the real structure of the earth's exposed surface, that all general classifications of rocks are premature; and it seems useless to attempt any others than those which are comparatively local, calculated for temporary purposes, and of such a nature as not to impede by an assumption of more knowledge than we possess, the general advancement of geology.

* The first part of this paper has been published in the Annales des Sciences Naturelles for September.

N. S. Vol.6. No.36. Dec. 1829.

$3 \mathrm{M}$

Clas- 
450 Mr. De la Beche's Classification of European Rocks.

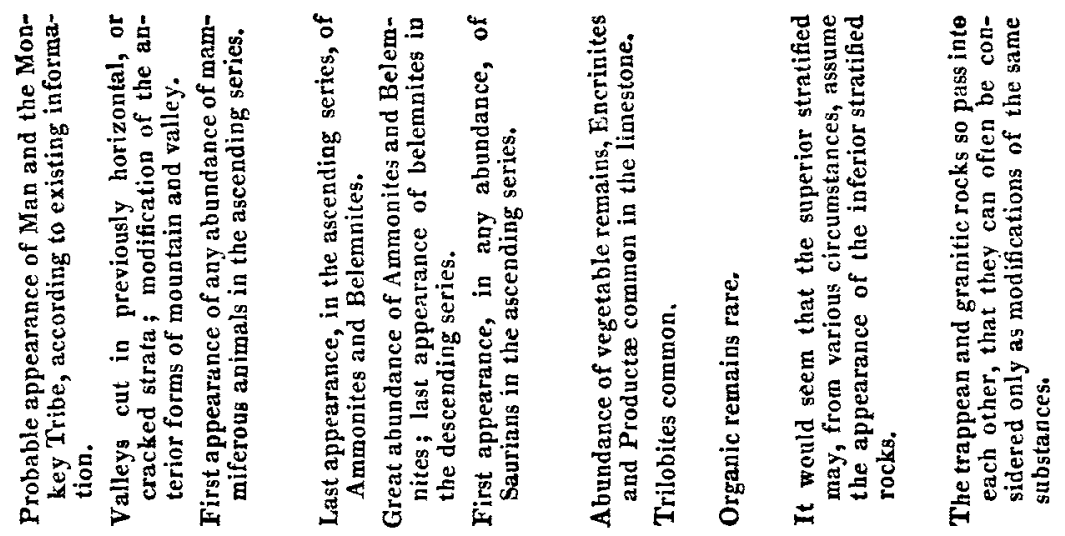
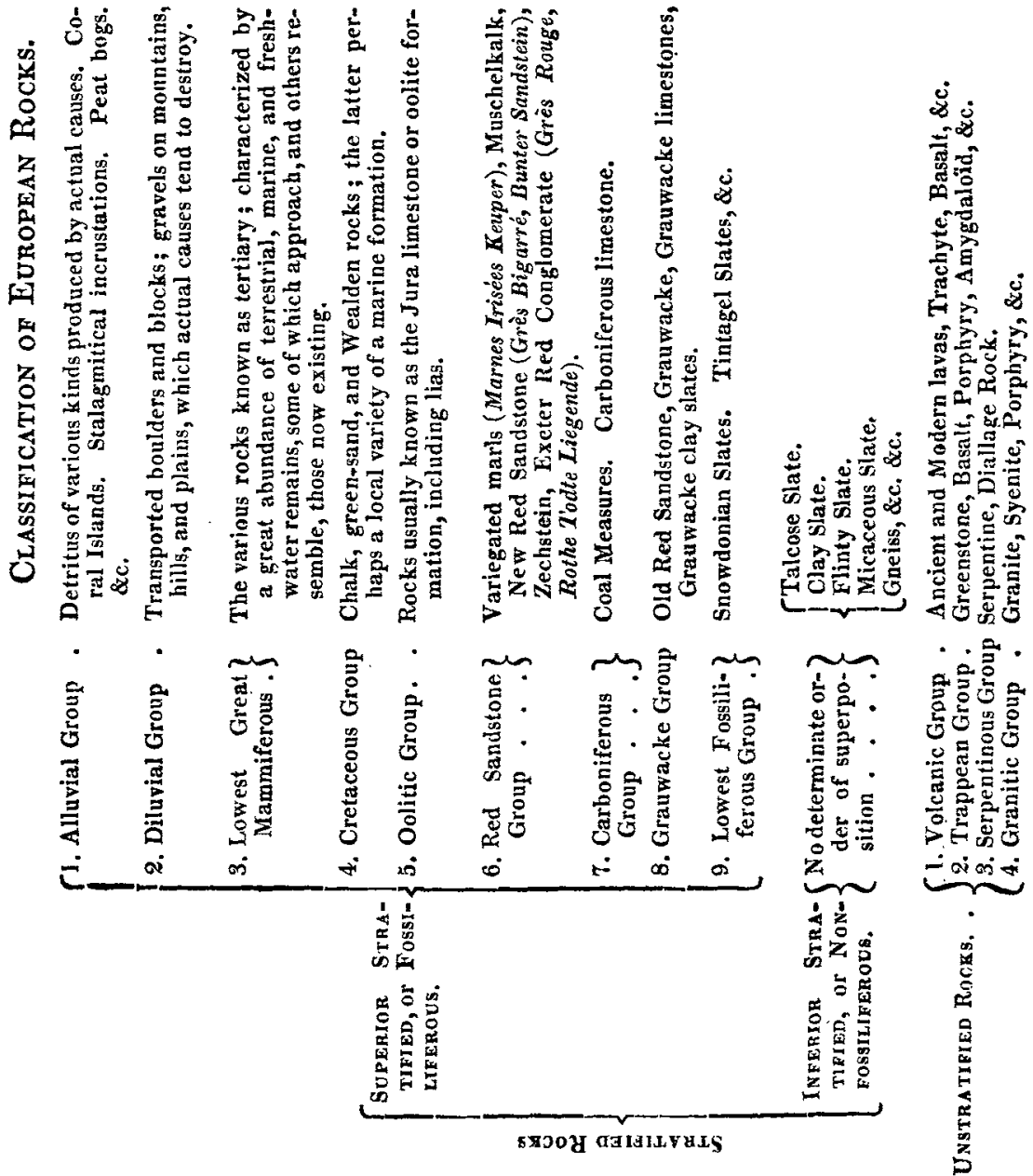